\title{
Predicted efficacy of the Palestinian wheat flour fortification programme: complementary analysis of biochemical and dietary data
}

\author{
Ziad Abdeen ', Asa'd Ramlawi ${ }^{2}$, Radwan Qaswari ${ }^{1}$, Ala' Abu Alrub ${ }^{2}$, Omar Dary ${ }^{3, *}, \dagger$, \\ Zo Rambeloson ${ }^{3}$, Setareh Shahab-Ferdows ${ }^{4}$, Daphna Dror ${ }^{4}$, Lindsay H Allen ${ }^{4}$, \\ Alicia Carriquiry ${ }^{5}$, Rand Salman ${ }^{3} \ddagger$ and Sahar Dkeidek ${ }^{1}$ \\ ${ }^{1}$ Nutrition and Health Research Institute, Al-Quds University, Jerusalem, Israel: ${ }^{2}$ Ministry of Health, Palestinian \\ Authority, Ramallah, West Bank, Palestinian Territories: ${ }^{3} \mathrm{~A} 2 \mathrm{Z} / \mathrm{The}$ USAID Project on Micronutrients and Child \\ Blindness, FHI-360, Washington DC, USA: ${ }^{4}$ USDA, ARS Western Human Nutrition Research Center, Davis, \\ CA, USA: ${ }^{5}$ Department of Statistics, lowa State University, Ames, IA, USA
}

Submitted 18 July 2013: Final revision received 8 January 2014: Accepted 23 June 2014: First published online 29 August 2014

\begin{abstract}
Objective: To utilize complementary biochemical and dietary data collected before the initiation of national flour fortification to (i) identify micronutrient insufficiencies or deficiencies and dietary inadequacies in Palestinian women and children in vulnerable communities and (ii) assess the suitability of the current wheat flour fortification formula.

Design: Quantitative dietary intake questionnaires were administered and fasting venous blood samples collected in randomly selected households in Gaza City and Hebron. The impact of fortification was simulated by estimating the additional micronutrient content of fortified wheat flour.

Setting: Households in Gaza City and Hebron that were not receiving food aid from social programmes.

Subjects: Non-pregnant women (18-49 years) and children aged 36-83 months. Results: The micronutrients with highest prevalence of insufficiency were vitamin $\mathrm{D}$ in women (84-97\% with serum 25-hydroxyvitamin $\mathrm{D}<50 \mathrm{nmol} / \mathrm{l}$ ) and vitamin $\mathrm{B}_{12}$ in women and children ( $43-82 \%$ with serum $\left.\mathrm{B}_{12}<221 \mathrm{pmol} / \mathrm{l}\right)$. Deficiencies of vitamin A, Fe and $\mathrm{Zn}$ were also of public health concern. Current levels of wheat flour fortificants were predicted to improve, but not eliminate, micronutrient intake inadequacies. Modification of fortificant concentrations of vitamin $\mathrm{D}$, thiamin, vitamin $\mathrm{B}_{12}, \mathrm{Zn}$ and folic acid may be indicated.

Conclusions: Micronutrient insufficiencies or deficiencies and intake inadequacies were prevalent based on either biochemical or dietary intake criteria. Adjustments to the current fortification formula for wheat flour are necessary to better meet the nutrient needs of Palestinian women and children.
\end{abstract}

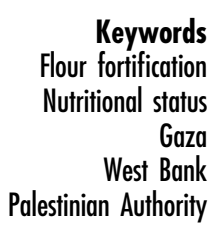

Biomarkers are considered the gold standard for assessing micronutrient status and serve as a tool to diagnose deficiency, a means of confirming adequacy of nutrient intake and a method for evaluating the impact of nutritional and health programmes over time. Dietary intake data are collected less frequently but are nevertheless critical to ensuring the success of many nutrition interventions. Dietary data serve to: (i) confirm that abnormal biochemical

$\dagger$ Present affiliation and address for correspondence: US Agency for International Development, Bureau for Global Health I HIDN, Ronald Reagan Building 3.7.40, 1300 Pennsylvania Avenue NW, Washington, DC 20523-3700, USA.

$\ddagger$ Present affiliation: World Health Organization, Ramallah, Palestine. values are due to inadequate intake rather than to other factors such as low bioavailability or disease; (ii) identify the main food sources of specific micronutrients; (iii) estimate the intake adequacy of micronutrients for which practical biomarkers are unavailable; and (iv) determine potential food vehicles for micronutrient fortification. Biochemical and dietary data can be used in a complementary manner to justify the need for, and to calculate the potential impact of, food fortification programmes for closing nutrient intake gaps.

Despite their complementary nature, cost and other limitations have precluded combined collection of biochemical and dietary data for nutritional surveillance, 
nutrition intervention monitoring, and programme evaluation efforts in most countries. The present study, carried out in Hebron and Gaza City in 2005, collected both biochemical and dietary data to assess nutrient intake distribution and status, and to model the impact of wheat flour fortification with eight vitamins (A, D, thiamin, riboflavin, niacin, $\mathrm{B}_{6}$, folic acid and $\mathrm{B}_{12}$ ) and two minerals ( $\mathrm{Fe}$ and $\mathrm{Zn}$ ). The objectives of the present work were to: (i) identify micronutrient deficiencies and dietary inadequacies in Palestinian women and children as a baseline for future nutritional surveillance; and (ii) assess whether the current wheat fortification formula, implemented as a national programme in 2006 , fulfils the dietary needs of these population groups.

\section{Methods}

The study was conducted according to the guidelines laid down in the Declaration of Helsinki and all procedures involving human subjects were approved by the Committee on Human Subjects Research at the Directorate of Primary Health Care and Public Health of the Ministry of Health of the Palestinian Authority and the Office of Research of Al-Quds University. Written informed consent was obtained from all adult participants.

Private dwellings in urban, non-urban and refugee camp settings in Hebron and Gaza City housing at least one non-pregnant woman aged 18-49 years and one child aged 36-83 months were selected using a multi-cluster random sampling method based on the census carried out by the Palestinian Center Bureau of Statistics in 1997. All data were collected in August 2005. Within each household, defined as 'all people sharing a common kitchen', one non-pregnant woman and child within the appropriate age range were randomly selected for inclusion in the survey. Age was ascertained by parental recall, identification cards or vaccination cards; record of date of birth is highly precise in these communities. During the survey, the interviewer excluded households that were registered to receive food assistance from the UN Relief and Works Agency or the World Food Programme.

A $24 \mathrm{~h}$ dietary recall questionnaire, training manual and food atlas were developed specifically for the survey. All foods and drinks consumed inside and outside the home were recorded. Mothers or caregivers answered questions regarding recipes or food preparation on behalf of children. The food atlas, developed using an average of weighed ingredients and post-weighed recipes cooked by eight families in different localities, was used to determine the nutrient content of foods prepared in the home. If foods were purchased, nutrient content was determined from the manufacturer's label, taking into account the proportion consumed. School menus were reviewed and analysed to ascertain the nutritional contribution of foods consumed at school.
To maximize respondent recall of foods eaten during the preceding day, the multiple-pass method $^{(1)}$ was used by trained fieldworkers. Briefly, the steps were: (i) a broad description of all food and beverage items consumed (quick list); (ii) a detailed description of each food or beverage, including method of preparation, in the quick list through interviewer prompts and questions; (iii) estimation of the amounts of each food or beverage and their corresponding ingredients; and (iv) a review of responses for completeness and accuracy. Questionnaires were validated through pilot studies conducted in one urban and one non-urban cluster. Repeat dietary recalls were conducted in $10 \%$ of participants on a nonconsecutive day to estimate intra-individual variation and to approximate the population usual intake profile. An independent trained nutritionist reviewed $20 \%$ of all interviews for accuracy of quantification, food codes and data entry.

\section{Blood samples and biomarker determination}

Fasting venous blood samples $(3-5 \mathrm{ml}$ each in two Vacutainer tubes) were obtained by medical technicians of the Ministry of Health from the same individuals interviewed for the dietary assessment and preserved at low temperature inside thermo containers. Vacutainers for serum collection were wrapped with aluminium foil immediately to prevent exposure to light and reserved for determination of biomarkers associated with nutrient status. Haematological parameters were measured in whole blood within $4 \mathrm{~h}$ of collection in automatic cell counters at medical centres in Hebron and in Gaza City. Serum was separated by centrifugation and stored in triplicate in cryovials for several days at $-20^{\circ} \mathrm{C}$. At the end of the collection period, samples were shipped to the Central Public Health Laboratory in the City of Ramallah, where they were stored at $-70^{\circ} \mathrm{C}$ pending analysis in the nutritional biochemistry laboratory of the US Department of Agriculture, Agricultural Research Service, Western Human Nutrition Research Center in Davis, CA, USA. Biomarker measurement was delayed until 2009 due to political constraints that limited cooperation with the Palestinian Authority from 2006 to 2008. A change in the political environment in 2009 allowed transfer outside the country of one-third of the samples, which were selected randomly. There were no controls for monitoring changes in biomarker contents while in storage, but no visual degradation or reduction of sample volume was detected.

All samples were analysed for vitamin D, folate and vitamin $\mathrm{B}_{12}$. Because retinol in children had already been measured in a nationwide survey in $2003^{(2)}$, remaining sample aliquots from children were preferentially reserved for measurement of ferritin and $\mathrm{Zn}$. Due to insufficient sample volume, retinol but not $\mathrm{Zn}$ or ferritin was determined in women. Nutritional insufficiency or deficiency was defined by biochemical cut-offs established by expert committee consensus (Table 1). 


\section{Nutrient intake calculations}

To calculate nutrient intakes, foods and beverages from the questionnaire were matched to food composition data from the SurvNet Composition Database supplemented by British and Israeli nutrient composition databases ${ }^{(3)}$. The estimated nutrient content of prepared foods took into consideration weight and nutrient losses during cooking and adjustments were made to account for variation in bioavailability of nutrients according to food source.

Dietary $\mathrm{Fe}$ and $\mathrm{Zn}$ were estimated at 5\% and 15\% bioavailability, respectively, assuming that the Palestinian diet is high in mineral absorption inhibitors (fibre, phytates and polyphenols) coming from chickpeas, thyme (za'atar), high extraction flours and tea. Vitamin $\mathrm{B}_{12}$ supplied by liver was divided by 5 to account for inefficient absorption when consumed from this source ${ }^{(4)}$. To estimate retinol activity equivalents, $\beta$-carotene intake from fruits and roots was divided by 12 , while $\beta$-carotene from green leafy vegetables was divided by $24^{(5)}$.

Usual nutrient intake distributions were estimated for vitamin $A$, thiamin $\left(B_{1}\right)$, riboflavin $\left(B_{2}\right)$, niacin, $B_{6}$, folate, $\mathrm{B}_{12}, \mathrm{Fe}, \mathrm{Zn}$ and $\mathrm{Ca}$ by adjusting the actual intake distribution for intra-individual variance using the Iowa State University Method ${ }^{(6)}$. Because the subset of individuals with repeat dietary recalls was small for the intraindividual variation found in the present study, the method was modified to estimate intra-individual variance as the weighted average of the within-person variance computed from the study data and an external variance estimate from the National Health and Nutrition Examination Survey conducted in the USA from 2003 to $2004^{(7)}$. Intakes of $\mathrm{Cu}, \mathrm{P}, \mathrm{Na}, \mathrm{K}, \mathrm{Mg}$, carbohydrates, protein, fibre, energy, cholesterol, saturated fat, monounsaturated fat, polyunsaturated fat and total fat were also estimated, and can be found in the original report of the survey ${ }^{(8)}$.

Prevalence of inadequate nutrient intakes was calculated using the Estimated Average Requirement (EAR) cut-off point method, ${ }^{(9)}$ which assumes that: (i) intake and requirements are independent; (ii) the requirement distribution is symmetric around its mean; and (iii) the variance of requirements in the group is higher than the variance of usual intake. To obtain a prevalence estimate for inadequate intake of $\mathrm{Ca}$, which had an Adequate Intake (AI) but no EAR at the time of the study, a weighted average of probability of inadequacy was calculated using the method of Foote et $a l .{ }^{(10)}$. Ca intake inadequacy was recalculated following release of the new EAR values in $2010^{(11)}$. For $\mathrm{Fe}$, which has an asymmetric requirement distribution precluding use of the EAR, a probability approach was used to estimate prevalence of inadequate intake ${ }^{(5)}$. Fe intake inadequacy risk estimate tables compiled by the Institute of Medicine ${ }^{(12)}$ were adapted for a lower bioavailability of dietary Fe (5\%) in the Palestinian diet.

To simulate the impact of wheat flour fortification with eight vitamins and two minerals as mandated by the Palestinian Wheat Flour Fortification Standard of 2006, estimates of the additional micronutrient content following 
Table 2 Predicted additional content of micronutrients in fortified wheat flour at bakeries or at the household level, before being used to prepare bread and other flour-containing foods

\begin{tabular}{|c|c|c|c|}
\hline Micronutrient & $\begin{array}{c}\text { Factory additional } \\
\text { mean content }(\mathrm{mg} / \mathrm{kg})\end{array}$ & $\begin{array}{l}\text { Estimated loss to } \\
\text { homes }(\%)^{*}\end{array}$ & $\begin{array}{l}\text { Estimated additional mear } \\
\text { content in homes }(\mathrm{mg} / \mathrm{kg})\end{array}$ \\
\hline Vitamin A (RAE) & 1.5 & 20 & $1 \cdot 2$ \\
\hline Vitamin D & 0.023 & 20 & 0.018 \\
\hline Thiamin $\left(\mathrm{B}_{1}\right)$ & $2 \cdot 9$ & 30 & $2 \cdot 0$ \\
\hline Riboflavin $\left(\mathrm{B}_{2}\right)$ & 3.6 & 15 & 3.1 \\
\hline Niacin & 35 & 15 & 30 \\
\hline Vitamin $\mathrm{B}_{6}$ & 3.6 & 15 & 3.1 \\
\hline Folate (as folic acid, DFE) & 2.5 & 15 & $2 \cdot 1$ \\
\hline Vitamin $\mathrm{B}_{12}$ & 0.004 & 15 & 0.003 \\
\hline Zn (from zinc oxide) & 20 & 0 & 20 \\
\hline $\mathrm{Fe}$ (from ferrous sulfate) & 34 & 0 & 34 \\
\hline
\end{tabular}

RAE, retinol activity equivalents; DFE, dietary folate equivalents.

*Values generally accepted based on experience with wheat flour and other foods ${ }^{(13-19)}$

†The DFE shown are calculated as folic acid multiplied by 1.7 because of the higher bioavailability of this compound over natural sources of folate.

losses in transport, storage and food preparation (Table 2) were used to modify the nutrient composition of all foods containing wheat flour ${ }^{(13-19)}$.

\section{Sample size}

Sample sizes were calculated for each subgroup based on an anticipated $15 \%$ change in the proportion of nutrient intakes less than the EAR in the fortification simulation, assuming $50 \%$ of intakes to be less than the EAR at baseline to yield the maximum sample size necessary to detect a change of this magnitude. The procedure yielded a sample size of 174 households per region, which was buffered by $5 \%$ to 183 households per region. In total, 366 households were surveyed (183 in each of two regions).

\section{Statistical analysis}

The statistical software package SAS version 9.3 and Personal Computer Software for Intake Distribution Estimation (PCSIDE; Department of Statistics, Iowa State University, Ames, IA, USA) were used for all statistical analyses. Summary statistics and initial tests of normality and equality of variance were calculated for nutrient biomarker and intake information by region (Hebron and Gaza City) and by target group. Nutrient intake and biomarker distributions tend to be rightskewed; thus, the non-parametric Mann-Whitney test was used to check for differences in central tendency between groups. The Mantel-Haenszel $\chi^{2}$ test with $\alpha=0.05$ was used to compare categorical variables (i.e. $0=$ usual intake below EAR or deficiency, $1=$ usual intake at or above EAR or adequacy) and proportions by region and age group, as well as before and after fortification ${ }^{(20)}$.

\section{Results}

\section{Demographic characteristics, food and energy intakes}

Data were collected from 366 mother-child pairs in Hebron and Gaza City (Table 3). Children's age range, gender, and maternal and paternal education were similar in the two regions. A higher proportion of households in Hebron than in Gaza City were located in rural areas (63.4\% v. $2 \cdot 2 \%$, while in Gaza City the proportions of households in urban areas (83.1\%) and refugee camps (14.8\%) were higher than in Hebron $(30 \cdot 1 \%$ and $6.6 \%$, respectively). The proportion of households with refugee status was higher in Gaza City than Hebron (57.9\% v. 9.8\%), although many refugees did not reside in the refugee camps.

Wheat flour, mainly in the form of pita bread, constituted the main source of energy (21-23\%), protein (21-23\%) and carbohydrates (34-36\%) for all age groups. Women and children in Gaza City consumed greater amounts of wheat flour and sandwich falafel (chickpeas) but smaller amounts of rice, fruits, eggs and milk than those in Hebron. A notable difference between children and women was the contribution to energy from sugar, sweets and beverages - including soft drinks - which represented $11 \%$ of the daily energy intake in children compared with $4 \%$ in women. Animal-source foods (meat, chicken, eggs and milk products) contributed less than $20 \%$ of the daily energy intake at both sites.

\section{Biochemical markers}

Among women, $12 \%$ (9\% in Hebron and 15\% in Gaza City) had low concentrations of serum retinol $(<0.7 \mu \mathrm{mol} / \mathrm{l}$; Table 4) and $63 \%$ had marginal concentrations ( $<1.05 \mu \mathrm{mol} / \mathrm{l})$. Vitamin D insufficiency (serum 25-hydroxyvitamin D $(25(\mathrm{OH}) \mathrm{D})<50 \mu \mathrm{mol} / \mathrm{l})$ was found in $90 \%$ of women but in less than $15 \%$ of children in both regions. The prevalence of vitamin D insufficiency was lower in Hebron than in Gaza City for children aged 36-59 months (5\%v. 13\%, $P=0.04$ ) and women $(84 \% v$. $97 \%, P=0.002)$. Furthermore, the median serum $25(\mathrm{OH}) \mathrm{D}$ concentration was significantly higher in Hebron than in Gaza City in children aged 60-83 months $(P<0 \cdot 04)$ and women $(P<0 \cdot 001)$. Among women, $56 \%$ and $70 \%$ in Hebron and Gaza City, respectively, had very low serum vitamin $\mathrm{D}$ concentrations $(<27.5$ $\mu \mathrm{mol} / \mathrm{l}$; data not shown). 
Table 3 Demographic characteristics of the study population: non-pregnant women (18-49 years) and children aged 36-83 months, Hebron and Gaza City, Palestine, August 2005

\begin{tabular}{|c|c|c|c|c|c|c|}
\hline \multirow[b]{2}{*}{ Parameter } & \multicolumn{2}{|c|}{ Hebron } & \multicolumn{2}{|c|}{ Gaza } & \multicolumn{2}{|c|}{ Total } \\
\hline & $n$ & $\%$ & $n$ & $\%$ & $n$ & $\%$ \\
\hline \multicolumn{7}{|l|}{ Gender of children } \\
\hline Female & 92 & $50 \cdot 0$ & 90 & 49.5 & 182 & $49 \cdot 7$ \\
\hline Male & 92 & $50 \cdot 0$ & 92 & 50.5 & 184 & $50 \cdot 3$ \\
\hline Households per district & 183 & $50 \cdot 0$ & 183 & $50 \cdot 0$ & 366 & $100 \cdot 0$ \\
\hline \multicolumn{7}{|l|}{ Locality of the households } \\
\hline Urban & 55 & $30 \cdot 1$ & 152 & 83.1 & 207 & $56 \cdot 6$ \\
\hline Rural & 116 & 63.4 & 4 & $2 \cdot 2$ & 120 & $32 \cdot 8$ \\
\hline Refugee camp & 12 & $6 \cdot 6$ & 27 & 14.8 & 39 & $10 \cdot 7$ \\
\hline \multicolumn{7}{|l|}{ Refugee status } \\
\hline Yes & 18 & $9 \cdot 8$ & 106 & 57.9 & 124 & 33.9 \\
\hline No & 165 & $90 \cdot 2$ & 77 & $42 \cdot 1$ & 242 & $66 \cdot 1$ \\
\hline \multicolumn{7}{|l|}{ Mother's education } \\
\hline Less than high school & 95 & 51.9 & 91 & 49.7 & 186 & $50 \cdot 8$ \\
\hline High school & 70 & 38.3 & 78 & $42 \cdot 6$ & 148 & $40 \cdot 4$ \\
\hline More than high school & 18 & $9 \cdot 8$ & 14 & $7 \cdot 7$ & 32 & 8.7 \\
\hline \multicolumn{7}{|l|}{ Father's education } \\
\hline Less than high school & 96 & 52.5 & 101 & $55 \cdot 2$ & 197 & 53.8 \\
\hline High school & 59 & $32 \cdot 2$ & 54 & 29.5 & 113 & $30 \cdot 9$ \\
\hline More than high school & 28 & $15 \cdot 3$ & 28 & $15 \cdot 2$ & 56 & $15 \cdot 3$ \\
\hline \multicolumn{7}{|c|}{ Children's age categories (months) } \\
\hline $36-59$ & 83 & $45 \cdot 6$ & 92 & $50 \cdot 0$ & 175 & $47 \cdot 8$ \\
\hline $60-83$ & 100 & $54 \cdot 4$ & 91 & $50 \cdot 0$ & 191 & $52 \cdot 2$ \\
\hline
\end{tabular}

The prevalence of low concentrations of serum folate $(<10 \mathrm{nmol} / \mathrm{l})$ was $\leq 6 \%$ for all age groups in both regions. Nevertheless, the median level of serum folate was lower in women in Hebron compared with Gaza City $(P=0.001)$ and the proportion of women in Hebron with serum folate concentrations $<16 \mathrm{nmol} / 1$ was significantly greater than in Gaza City ( $44 \%$ v. $24 \%, P<0 \cdot 05)$. In contrast, vitamin $\mathrm{B}_{12}$ deficiency (serum $\mathrm{B}_{12}<221 \mathrm{pmol} / \mathrm{l}$ ) was more prevalent in Gaza City than in Hebron in both women $(82 \% v$. $58 \%, P<0.001)$ and children aged 60-83 months (60\% $v$. $46 \%, P=0.04)$. Among children aged 36-59 months interregional differences in serum vitamin $\mathrm{B}_{12}$ were not significant and deficiency rates were greater than $40 \%$.

More than $23 \%$ of children in both regions had low concentrations of serum $\mathrm{Zn}(<65 \mu \mathrm{g} / \mathrm{dl})$. While there were no significant differences in prevalence of $\mathrm{Zn}$ deficiency between regions, children aged 36-59 months had a significantly higher prevalence of $\mathrm{Zn}$ deficiency than children aged 60-83 months in Hebron (39\% v. 26\%, $P=0.049)$ but not in Gaza City. In contrast, children aged 60-83 months had a significantly higher prevalence of Fe deficiency (serum ferritin $<12$ or $15 \mu \mathrm{g} / \mathrm{l}$ ) than the younger age group in Hebron ( $28 \% v .15 \%, P=0.025)$. Children aged 36-59 months in Gaza City had a significantly higher prevalence of Fe deficiency than those in Hebron $(30 \% v$. $15 \%, P=0 \cdot 011)$. The median serum ferritin concentration was also lower in Gaza City $(P=0.03)$ for this age group.

The prevalence of anaemia as measured by $\mathrm{Hb}$ levels did not differ significantly between regions except among children aged 60-83 months, for whom the prevalence was significantly higher in Gaza City than in Hebron $(20 \%$ v. 9\%, $P=0.03$ ). Anaemia assessed through $\mathrm{Hb}$ was significantly more prevalent in women (32\%) than in children aged 36-59 months (21\%) and 60-83 months ( $15 \%)$ in both regions $(P<0.05$ for all). As measured by haematocrit, the prevalence of anaemia was higher in Gaza City compared with Hebron in both children aged 60-83 months (28\% v. $11 \%, P=0.001)$ and women $(39 \%$ v. $21 \%, P=0.005)$. The prevalence of anaemia assessed by haematocrit was significantly lower than that assessed by $\mathrm{Hb}$ among children aged 36-59 months $(P<0.05)$, but not in women and children aged 60-83 months.

\section{Micronutrient intake inadequacy compared with biochemical markers}

Results from Hebron and Gaza City were combined to increase the precision of estimated intake quantities. Both dietary and biochemical data were available for the following micronutrients in each age group: vitamin $\mathrm{B}_{12}$, folate, Fe and $\mathrm{Zn}$ in children aged 36-59 months; folate, Fe and $\mathrm{Zn}$ in children aged 60-83 months; and folate, vitamin A and Fe (as anaemia rather than deficiency) in women (Table 5).

Among all age groups, prevalence estimates of folate inadequacy were significantly higher when based on dietary data rather than on serum markers $(P<0.001$ for all). In children aged 36-59 months the estimate of vitamin $\mathrm{B}_{12}$ deficiency was significantly lower based on dietary compared with biochemical data (27 v. $48 \%, P<0.001)$; comparison for the other two age groups could not be made for this nutrient. Zn intake inadequacy was significantly greater than serum deficiency in children (74$89 \%$ v. 24-34\%, $P<0 \cdot 001)$ while Fe deficiency prevalence did not differ significantly when estimated by dietary or biochemical analysis. In women, the prevalence of $\mathrm{Fe}$ 
Table 4 Biomarker and biochemical nutrient insufficiencies or deficiencies in women and children of Hebron and Gaza City, Palestine, August 2005

\begin{tabular}{|c|c|c|c|c|c|c|c|c|c|c|}
\hline \multirow[b]{2}{*}{ Indicator } & \multicolumn{4}{|c|}{ Hebron } & \multicolumn{4}{|c|}{ Gaza City } & \multirow[b]{2}{*}{$P$ (Median) $\dagger$} & \multirow[b]{2}{*}{$P$ (Def. \%) $\ddagger$} \\
\hline & $n$ & Median $\left(P_{50}\right)$ & IQR $\left(P_{25}-P_{75}\right)$ & Def. $(\%)^{\star}$ & $n$ & Median $\left(P_{50}\right)$ & IQR $\left(\mathrm{P}_{25}-\mathrm{P}_{75}\right)$ & Def. $(\%)^{*}$ & & \\
\hline \multicolumn{11}{|c|}{ Non-pregnant women $18-49$ years } \\
\hline Serum vitamin A ( $\mu \mathrm{g} / \mathrm{dl})$ & 75 & 28.5 & $23 \cdot 7-33 \cdot 1$ & 9 & 66 & $28 \cdot 8$ & $22 \cdot 6-33 \cdot 0$ & 15 & NS & NS \\
\hline Serum vitamin D (umol/l) & 87 & 24 & $17-41$ & 84 & 69 & 10 & $10-26$ & 97 & $<0.001$ & 0.002 \\
\hline Serum folate $(\mathrm{nmol} / \mathrm{l})$ & 66 & 18.5 & $13.2-24.4$ & 3 & 51 & 23.8 & $18.5-31.8$ & 2 & 0.001 & NS \\
\hline Serum vitamin $\mathrm{B}_{12}(\mathrm{pmol} / \mathrm{l})$ & 66 & 196 & $142-262$ & 58 & 51 & 128 & $73-183$ & 82 & 0.002 & $<0.001$ \\
\hline Serum Zn $(\mu \mathrm{g} / \mathrm{dl})$ & - & - & - & - & - & - & - & - & - & - \\
\hline Serum ferritin $(\mu \mathrm{g} / \mathrm{l})$ & - & _- & _ & - & _ & _- & _- & _ & _ & _- \\
\hline $\mathrm{Hb}(\mathrm{g} / \mathrm{l})$ & 87 & 126 & $118-135$ & 29 & 69 & 123 & $116-131$ & 36 & NS & NS \\
\hline Haematocrit (\%) & 87 & 39 & $36 \cdot 1-40 \cdot 6$ & 21 & 69 & 37 & $34.9-39 \cdot 3$ & 39 & NS & 0.005 \\
\hline \multicolumn{11}{|l|}{ Children $36-59$ months } \\
\hline Serum vitamin $A(\mu \mathrm{g} / \mathrm{dl})$ & - & - & - & - & - & - & - & - & - & - \\
\hline Serum vitamin $D(\mu \mathrm{mol} / /)$ & 37 & 66 & $61-91$ & 5 & 45 & 71 & 55-84 & 13 & NS & 0.04 \\
\hline Serum folate $(\mathrm{nmol} / \mathrm{l})$ & 42 & 34.5 & $23 \cdot 2-42 \cdot 3$ & 0 & 53 & 36.9 & $25 \cdot 1-40.9$ & 6 & NS & 0.01 \\
\hline Serum vitamin $\mathrm{B}_{12}(\mathrm{pmol} / \mathrm{l})$ & 42 & 301 & $152-377$ & 52 & 53 & 236 & $136-358$ & 43 & NS & NS \\
\hline Serum Zn $(\mu \mathrm{g} / \mathrm{dl})$ & 23 & 109 & $56-113$ & 39 & 21 & 71 & $62-77$ & 29 & 0.06 & NS \\
\hline Serum ferritin $(\mu \mathrm{g} / \mathrm{l})$ & 40 & 19.8 & $14 \cdot 6-33 \cdot 1$ & 15 & 33 & $17 \cdot 3$ & $9 \cdot 4-28 \cdot 3$ & 30 & 0.03 & 0.011 \\
\hline $\mathrm{Hb}(\mathrm{g} / \mathrm{l})$ & 41 & 127 & $116-129$ & 20 & 53 & 125 & $116-126$ & 21 & NS & NS \\
\hline Haematocrit (\%) & 41 & 38 & $34.6-38.4$ & 9 & 53 & 36 & $34 \cdot 1-37 \cdot 1$ & 9 & 0.06 & NS \\
\hline \multicolumn{11}{|l|}{ Children $60-83$ months } \\
\hline Serum vitamin $A(\mu \mathrm{g} / \mathrm{dl})$ & - & - & - & - & - & - & - & - & - & - \\
\hline Serum vitamin $D(\mu \mathrm{mol} / /)$ & 45 & 80 & $64-94$ & 9 & 42 & 64 & 55-80 & 12 & 0.04 & NS \\
\hline Serum folate $(\mathrm{nmol} / \mathrm{l})$ & 44 & 29 & $24.5-34.4$ & 0 & 47 & 32 & $23 \cdot 8-42 \cdot 2$ & 0 & NS & NS \\
\hline Serum vitamin $B_{12}(\mathrm{pmol} / \mathrm{l})$ & 44 & 331 & $156-352$ & 46 & 47 & 174 & $107-274$ & 60 & NS & 0.04 \\
\hline Serum Zn $(\mu \mathrm{g} / \mathrm{dl})$ & 19 & 104 & $63-105$ & 26 & 26 & 75 & $65-80$ & 23 & 0.08 & NS \\
\hline Serum ferritin $(\mu \mathrm{g} / \mathrm{l})$ & 43 & 22 & $13 \cdot 6-37 \cdot 1$ & 28 & 38 & 26 & $12 \cdot 1-42 \cdot 3$ & 34 & NS & NS \\
\hline $\mathrm{Hb}(\mathrm{g} / \mathrm{l})$ & 44 & 127 & $119-132$ & 9 & 50 & 122 & $118-127$ & 20 & NS & 0.03 \\
\hline Haematocrit (\%) & 44 & 38 & $35 \cdot 9-39.2$ & 11 & 50 & 36 & $34 \cdot 8-37 \cdot 4$ & 28 & NS & 0.001 \\
\hline
\end{tabular}

IQR, interquartile range; Def., deficiency.

th points presented in Table 1.

in median value between Hebron and Gaza.

$\neq x^{2}$ Mantel-Haenszel test for difference in proportion of deficiency between Hebron and Gaza. 
Table 5 Prevalence (\%) of micronutrient insufficiencies or deficiencies as identified by biomarkers and nutrient intakes in women and children of Hebron and Gaza City, Palestine, August 2005

\begin{tabular}{|c|c|c|c|c|c|c|c|c|c|}
\hline \multirow[b]{2}{*}{ Micronutrient } & \multicolumn{3}{|c|}{ Children 36-59 months } & \multicolumn{3}{|c|}{ Children $60-83$ months } & \multicolumn{3}{|c|}{ Women $18-49$ years } \\
\hline & Marker & Intake* & $P$ value & Marker & Intake* & $P$ value & Marker & Intake* & $P$ value \\
\hline \multirow[t]{2}{*}{ Vitamin A } & 26† & 47 & 0.002 & - & 63 & - & 12 & 45 & 0.001 \\
\hline & $76 \dagger \ddagger \S$ & - & $<0.001$ & - & - & - & $63 \ddagger$ & - & 0.010 \\
\hline Vitamin D & 9 & - & - & 10 & - & - & 90 & - & - \\
\hline Folate & 4 & 44 & $<0.001$ & 0 & 89 & $<0.001$ & $\begin{array}{c}3 \\
34 \neq\end{array}$ & 93 & $\begin{array}{l}<0.001 \\
<0.001\end{array}$ \\
\hline Vitamin $\mathrm{B}_{12}$ & 48 & 27 & $<0.001$ & 53 & N/A & - & 70 & $\mathrm{~N} / \mathrm{A}$ & - \\
\hline Zn (low bioavailability) & 34 & 74 & $<0.001$ & 24 & 89 & $<0.001$ & - & 71 & - \\
\hline Fe (low bioavailability) & 18 & 9 & 0.062 & 31 & 42 & 0.106 & - & 100 & - \\
\hline Anaemia $(\mathrm{Hb})$ & 21 & - & - & 15 & - & - & 32 & - & - \\
\hline Anaemia (haematocrit) & 9 & - & - & 20 & - & - & 29 & - & - \\
\hline
\end{tabular}

N/A, not applicable; EAR, Estimated Average Requirement; AI, Adequate Intake

*Proportion of the population with intake less than the EAR or less than the Al for Fe.

tData from a national survey conducted in $2003^{(2)}$.

$\ddagger$ Alternative cut-off points: serum retinol $<1.05 \mu \mathrm{mol} / \mathrm{l}$, serum folate $<16 \mathrm{nmol} / \mathrm{l}$.

$\S$ Due to large intra-individual variation in intake.

intake inadequacy (100\%) was greater than the prevalence of anaemia based on $\mathrm{Hb}$ or haematocrit (32 and 30\%). Prevalence estimates for vitamin A insufficiency in women (and in children using biomarker data from the vitamin A survey of $2004^{(2)}$ ) differed significantly between biomarker and intake results $(P \leq 0 \cdot 01)$, but the measure resulting in a higher estimate of inadequacy depended upon the choice of serum retinol cut-off $(<0 \cdot 7 v .<1.05 \mu \mathrm{mol} / \mathrm{l})$.

\section{Estimated impact of wheat flour fortification in women and children}

Based on the simulation, fortification of wheat flour using the current Palestinian formula would reduce the prevalence of micronutrient intake inadequacies in Hebron and Gaza City in all age groups considered in the study but most substantially in women, the group with the highest daily consumption of flour (Table 6). In women, flour fortification was predicted to reduce the prevalence of intake inadequacy significantly for vitamin $\mathrm{A}$, thiamin, riboflavin, niacin, vitamin $\mathrm{B}_{6}$, folate and $\mathrm{Zn}(P<0.001$ for all). Intake inadequacies among women following fortification were predicted to be $<30 \%$ for vitamin A, riboflavin and vitamin $\mathrm{B}_{6}$. However, fortification was not predicted to have a significant impact on $\mathrm{Fe}$ intake inadequacy in women ( $98 \%$ inadequacy following fortification), nor was it predicted to reduce thiamin intake inadequacy sufficiently (77\% inadequacy following fortification). Other nutrients with expected intake inadequacy prevalence $\geq 30 \%$ in women following fortification were niacin, folate, vitamin $\mathrm{B}_{12}$ and $\mathrm{Zn}$.

Children aged 36-59 months were predicted to experience significant reductions in the prevalence of intake inadequacy for vitamin A $(P=0.008)$, thiamin $(P<0.001)$, niacin $(P<0.001)$, folate $(P<0.001), \mathrm{Zn}(P=0.004)$ and Fe $(P=0 \cdot 009)$. However, even after fortification of flour with vitamin $\mathrm{A}$ and $\mathrm{Zn}$, the prevalence of inadequate intake was predicted to be $29 \%$ and $72 \%$, respectively, in children in this age range. Among children aged 60-83 months, a significant reduction in intake inadequacy following wheat flour fortification was predicted for vitamin A $(P=0 \cdot 022)$, thiamin $(P=0 \cdot 023)$, riboflavin $(P<0 \cdot 001)$, niacin $(P<0 \cdot 001)$, vitamin $\mathrm{B}_{6}(P<0 \cdot 001)$, folate $(P<0.001)$, $\mathrm{Zn}(P=0.003)$ and $\mathrm{Fe}(P<0 \cdot 001)$. Given the higher needs of this age group, however, it was estimated that the prevalence of nutrient intake inadequacies would remain high following fortification for vitamin A ( $47 \%)$, thiamin ( $81 \%)$, riboflavin $(35 \%)$, niacin ( $48 \%)$, folate $(41 \%)$, vitamin $\mathrm{B}_{12}$ (49\%) and Zn (85\%).

\section{Discussion}

The present study is one of the first of its kind to ascertain micronutrient status of a population through a complementary analysis of serum biomarkers and dietary intakes. Both types of data provide compelling evidence of micronutrient insufficiencies or deficiencies among Palestinian women and children aged 36-83 months from Hebron and Gaza City. Based on analysis of serum biomarkers there was a high prevalence of vitamin $B_{12}$ deficiency both in children and women (43-82\%) and of vitamin D insufficiency in women (84-97\%). Anaemia was found in $21 \%$ of children aged 36-59 months, $15 \%$ of children aged $60-83$ months and $32 \%$ of women; $\mathrm{Fe}$ deficiency is likely to be a main contributing factor as suggested by corresponding low serum ferritin in children aged 36-59 months (18\%) and 60-83 months (31\%). Zn deficiency was observed in $24-34 \%$ of children and vitamin A deficiency in $12 \%$ of women (using the cut-off point of $0.7 \mu \mathrm{mol} / 1$; $63 \%$ if using the cut-off point of $1.05 \mu \mathrm{mol} / \mathrm{l}$ ). The combination of vitamin $\mathrm{B}_{12}, \mathrm{Fe}, \mathrm{Zn}$ and vitamin $\mathrm{A}$ inadequacies is consistent with a diet poor in foods from animal sources. Overall, the population of Gaza City was more affected by vitamin $\mathrm{D}$, vitamin $\mathrm{B}_{12}$ and Fe deficiencies, but less by folate deficiency, than the population of Hebron, 
Table 6 Estimated adequacy of micronutrient intakes for children and women, before and after introduction of fortified wheat flour, in Hebron and Gaza City, Palestine, August 2005

\begin{tabular}{|c|c|c|c|c|c|c|c|c|c|}
\hline \multirow[b]{2}{*}{ Indicator } & \multirow[b]{2}{*}{ EAR } & \multicolumn{3}{|c|}{ Before fortification } & \multicolumn{3}{|c|}{ After fortification } & \multirow[b]{2}{*}{$P$ (Median) $\dagger$} & \multirow[b]{2}{*}{$P$ (Inadeq. \%) $\ddagger$} \\
\hline & & Median $\left(P_{50}\right)$ & IQR $\left(P_{25}-P_{75}\right)$ & Inadeq. $(\%)^{*}$ & Median $\left(\mathrm{P}_{50}\right)$ & IQR $\left(P_{25}-P_{75}\right)$ & Inadeq. $(\%)^{\star}$ & & \\
\hline \multicolumn{10}{|c|}{ Women 18-49 years $(n 366)$} \\
\hline Vitamin A ( $\mu \mathrm{g} R A E / d)$ & 357 & 383 & $270-554$ & 45 & 659 & $464-998$ & 10 & $<0.001$ & $<0.001$ \\
\hline Vitamin $E(\mathrm{mg} / \mathrm{d})$ & $6 \cdot 3$ & $10 \cdot 0$ & $7 \cdot 9-12 \cdot 4$ & 10 & - & - & - & - & - \\
\hline Thiamin $\left(B_{1}\right)(\mathrm{mg} / \mathrm{d})$ & 0.9 & 0.6 & $0.5-0.7$ & 97 & 0.8 & $0.6-0.9$ & 77 & 0.002 & $<0.001$ \\
\hline Riboflavin $\left(\mathrm{B}_{2}\right)(\mathrm{mg} / \mathrm{d})$ & 0.9 & 0.8 & $0.7-1.0$ & 67 & $1 \cdot 1$ & $0.9-1.4$ & 27 & 0.001 & $<0.001$ \\
\hline Niacin $(\mathrm{mg} / \mathrm{d})$ & 11.0 & 9.4 & $7 \cdot 6-11.5$ & 70 & $12 \cdot 5$ & $10 \cdot 4-15 \cdot 0$ & 32 & 0.004 & $<0.001$ \\
\hline Vitamin $B_{6}(\mathrm{mg} / \mathrm{d})$ & $1 \cdot 1$ & 1.0 & $0.8-1.2$ & 61 & $1 \cdot 3$ & $1.1-1.5$ & 23 & 0.002 & $<0.001$ \\
\hline Folate ( $\mu \mathrm{g}$ DFE/d) & 320 & 202 & $162-249$ & 93 & 354 & 279-445 & 34 & $<0.001$ & $<0.001$ \\
\hline Vitamin $\mathrm{B}_{12}(\mu \mathrm{g} / \mathrm{d})$ & $2 \cdot 0$ & N/A & $\mathrm{N} / \mathrm{A}$ & $\mathrm{N} / \mathrm{A}$ & 3.1 & $1.8-5.5$ & 30 & - & - \\
\hline Vitamin $C(\mathrm{mg} / \mathrm{d})$ & 35 & 66 & $51-83$ & 6 & - & - & - & - & - \\
\hline $\mathrm{Zn}(\mathrm{mg} / \mathrm{d})$ & 8.0 & 6.9 & $5 \cdot 7-8 \cdot 3$ & 71 & 8.8 & $7 \cdot 4-10.5$ & 36 & $<0.001$ & $<0.001$ \\
\hline $\mathrm{Fe}(\mathrm{mg} / \mathrm{d})$ & $26 \cdot 0$ & 9.0 & $7 \cdot 2-11 \cdot 2$ & 100 & $12 \cdot 7$ & $10 \cdot 2-15 \cdot 8$ & 98 & $<0.001$ & NS \\
\hline $\mathrm{Ca}(\mathrm{mg} / \mathrm{d})$ & 800 & 304 & 179-472 & 94 & - & - & - & - & - \\
\hline \multicolumn{10}{|c|}{ Children $36-59$ months $(n 175)$} \\
\hline Vitamin A ( $\mu \mathrm{g} R A E / d)$ & 321 & 337 & 224-522 & 47 & 419 & $303-607$ & 29 & $<0.001$ & 0.008 \\
\hline Vitamin E $(\mathrm{mg} / \mathrm{d})$ & 4.0 & $8 \cdot 2$ & $6 \cdot 8-9 \cdot 8$ & 1 & - & - & - & - & - \\
\hline Thiamin $\left(B_{1}\right)(\mathrm{mg} / \mathrm{d})$ & 0.48 & 0.5 & $0.4-0.7$ & 43 & 0.6 & $0.5-1 \cdot 1$ & 17 & 0.045 & $<0.001$ \\
\hline Riboflavin $\left(\mathrm{B}_{2}\right)(\mathrm{mg} / \mathrm{d})$ & 0.48 & 0.7 & $0.6-0.9$ & 8 & 0.9 & $0.7-1 \cdot 1$ & 2 & 0.009 & NS \\
\hline Niacin $(\mathrm{mg} / \mathrm{d})$ & $6 \cdot 0$ & 7.5 & $6 \cdot 2-9 \cdot 0$ & 21 & $9 \cdot 2$ & $7 \cdot 8-10 \cdot 9$ & 5 & 0.001 & $<0.001$ \\
\hline Vitamin $B_{6}(\mathrm{mg} / \mathrm{d})$ & 0.48 & 0.9 & $0.7-1.0$ & 3 & 1.0 & $0.9-1.2$ & 0 & 0.001 & NS \\
\hline Folate ( $\mu \mathrm{g}$ DFE/d) & 160 & 167 & $138-201$ & 44 & 265 & $212-328$ & 7 & 0.000 & $<0.001$ \\
\hline Vitamin $B_{12}(\mu \mathrm{g} / \mathrm{d})$ & 1.0 & 1.6 & $1 \cdot 0-2 \cdot 8$ & 27 & 1.7 & $1 \cdot 1-2 \cdot 5$ & 20 & NS & NS \\
\hline Vitamin C (mg/d) & 25 & 61 & $46-79$ & 3 & - & - & - & - & - \\
\hline $\mathrm{Zn}(\mathrm{mg} / \mathrm{d})$ & 8.0 & $5 \cdot 7$ & $4 \cdot 8-6 \cdot 7$ & 91 & 7.0 & $5 \cdot 9-8 \cdot 2$ & 72 & $<0.001$ & 0.004 \\
\hline $\mathrm{Fe}(\mathrm{mg} / \mathrm{d})$ & $5 \cdot 0$ & $7 \cdot 2$ & $6 \cdot 0-8 \cdot 7$ & 9 & 9.5 & $7 \cdot 9-11 \cdot 3$ & 1 & $<0.001$ & 0.009 \\
\hline $\mathrm{Ca}(\mathrm{mg} / \mathrm{d})$ & 500 & 288 & $186-403$ & 83 & - & - & - & - & - \\
\hline \multicolumn{10}{|c|}{ Children 60-83 months ( $n$ 191) } \\
\hline Vitamin A ( $\mu \mathrm{g} R A E / d)$ & 357 & 285 & $186-455$ & 63 & 373 & $263-566$ & 47 & $<0.001$ & 0.022 \\
\hline Vitamin E $(\mathrm{mg} / \mathrm{d})$ & $5 \cdot 6$ & $8 \cdot 1$ & $6.9-9.5$ & 8 & - & - & - & - & - \\
\hline Thiamin $\left(\mathrm{B}_{1}\right)(\mathrm{mg} / \mathrm{d})$ & 0.7 & 0.5 & $0.3-0.6$ & 92 & 0.6 & $0.5-0.7$ & 81 & 0.008 & 0.023 \\
\hline Riboflavin $\left(B_{2}\right)(\mathrm{mg} / \mathrm{d})$ & 0.7 & 0.6 & $0.5-0.8$ & 62 & 0.8 & $0.6-1.0$ & 35 & 0.002 & $<0.001$ \\
\hline Niacin $(\mathrm{mg} / \mathrm{d})$ & $9 \cdot 0$ & $7 \cdot 2$ & $5.9-8 \cdot 8$ & 77 & $9 \cdot 1$ & $7 \cdot 3-11 \cdot 3$ & 48 & 0.000 & $<0.001$ \\
\hline Vitamin $B_{6}(\mathrm{mg} / \mathrm{d})$ & 0.80 & 0.8 & $0.7-1.0$ & 51 & 1.0 & $0.8-1.2$ & 22 & 0.002 & $<0.001$ \\
\hline Folate ( $\mu \mathrm{g}$ DFE/d) & 240 & 163 & $132-201$ & 89 & 261 & $202-334$ & 41 & $<0.001$ & $<0.001$ \\
\hline Vitamin $B_{12}(\mu \mathrm{g} / \mathrm{d})$ & 1.5 & N/A & $\mathrm{N} / \mathrm{A}$ & $\mathrm{N} / \mathrm{A}$ & 1.5 & $0.9-2.5$ & 49 & - & - \\
\hline Vitamin C (mg/d) & 29 & 54 & $40-71$ & 9 & - & - & - & - & - \\
\hline $\mathrm{Zn}(\mathrm{mg} / \mathrm{d})$ & 9.0 & $5 \cdot 2$ & $4 \cdot 3-6 \cdot 3$ & 97 & $6 \cdot 5$ & $5 \cdot 3-8 \cdot 0$ & 85 & 0.001 & 0.003 \\
\hline $\mathrm{Fe}(\mathrm{mg} / \mathrm{d})$ & $7 \cdot 0$ & $7 \cdot 4$ & $6 \cdot 1-8 \cdot 9$ & 42 & 9.5 & $7 \cdot 8-11 \cdot 6$ & 15 & $<0.001$ & $<0.001$ \\
\hline $\mathrm{Ca}(\mathrm{mg} / \mathrm{d})$ & 800 & 241 & $149-386$ & 99 & - & - & - & - & - \\
\hline
\end{tabular}

EAR, Estimated Average Requirement; IQR, interquartile range; Inadeq., inadequacy; RAE, retinol activity equivalents; DFE, dietary folate equivalents; N/A, not applicable.

"For Fe, intake inadequacy was calculated using a probability method; for the rest of micronutrients, it was the proportion below the specified EAR values. Low dietary bioavailability was assumed for Fe and Zn. †Mann-Whitney test for difference in median value before and after fortification.

$\mp x^{2}$ Mantel-Haenszel test for difference in proportion of inadequacy before and after fortification. 
consistent with the lower intakes of milk, eggs and meat, but higher intake of chickpeas in Gaza City.

Fortification of wheat flour with eight vitamins and two minerals using the current Palestinian formulation was predicted to reduce micronutrient intake inadequacies significantly in all age groups. However, even after fortification, intake inadequacy was estimated to remain unacceptably high for $\mathrm{Fe}(98 \%)$, thiamin (77\%), Zn (36\%), folate (34\%), niacin (32\%) and vitamin $\mathrm{B}_{12}(30 \%)$ in women; for vitamin $\mathrm{A}$ (29\%) and $\mathrm{Zn}(72 \%)$ in children aged 36-59 months; and for vitamin A ( $47 \%)$, thiamin (81\%), riboflavin (35\%), niacin (48\%), folate (41\%), vitamin $\mathrm{B}_{12}(49 \%)$ and $\mathrm{Zn}(85 \%)$ in children aged 60-83 months.

Several micronutrients assessed in the present study vitamin $\mathrm{D}$, folate, vitamin $\mathrm{B}_{12}$, vitamin $\mathrm{A}$ and $\mathrm{Fe}-$ require special consideration. While vitamin $\mathrm{D}$ is included in the wheat flour fortification formula, intake was not calculated in the dietary survey since the main source of vitamin $\mathrm{D}$ is skin exposure to ultraviolet light. The fact that vitamin D insufficiency (serum $25(\mathrm{OH}) \mathrm{D}<50 \mathrm{nmol} / \mathrm{l}$ ) was significantly more prevalent in women (90\%) than in children (10\%) and that severe deficiency (serum $25(\mathrm{OH}) \mathrm{D}<27.5 \mathrm{nmol} / \mathrm{l}$ ) was found in $>50 \%$ of women in the present study can be explained by women's low skin exposure to sunlight. A significantly higher prevalence of vitamin D insufficiency in women in Gaza City than in Hebron supports this hypothesis since exposure to sunlight is less common in the former. A high prevalence of vitamin D insufficiency in women has been described in other Middle Eastern countries ${ }^{(21-24)}$. The results of the study suggest that the content of vitamin D in the wheat flour may need to be increased. Although measurements were not made in men, who consume more flour and have greater exposure to sunlight, vitamin D excess resulting from increased concentration of the nutrient in fortified flour is highly improbable. At present, estimated intake of vitamin $\mathrm{D}$ for a person consuming fortified wheat flour $300 \mathrm{~g} / \mathrm{d}$ is $\sim 5.4 \mu \mathrm{g}$ ( $216 \mathrm{IU})$, which corresponds to slightly above half the EAR $(10 \mu \mathrm{g}(400 \mathrm{IU} / \mathrm{d}))$ and well below the upper limit $(100 \mu \mathrm{g} / \mathrm{d}(4000 \mathrm{IU} / \mathrm{d}))$ for adults. In addition to national fortification, targeted interventions may be needed to reduce the risk of osteomalacia in women and rickets in breast-fed offspring.

Despite the high estimates of prevalence of inadequate folate intake measured across age groups (44-93\%), biochemical evidence of deficiency was rare $(<4 \%)$. This discrepancy is likely due to food composition tables that underestimate folate content in the legumes (chickpeas and lentils) common in the traditional Palestinian diet. Folate content reported in most composition tables was measured before extraction techniques and analytical assays were refined in recent years. To better assess intake adequacy, the folate content of commonly consumed foods should be reassessed. Furthermore, serum folate and other micronutrients should be re-measured to determine the impact of wheat flour fortification implemented by the Palestinian Authority in 2006.
In spite of the near absence of frank folate deficiency, $35 \%$ of women in the present study had serum folate concentrations $<16 \mathrm{nmol} / 1$, consistent with an increased risk of neural tube defects in offspring ${ }^{(25)}$. In addition, deficiency of vitamin $\mathrm{B}_{12}$, which is independently associated with the occurrence of neural tube defects ${ }^{(26)}$, was highly prevalent among women of reproductive age (70\%). Together, these data suggest that an additional supply of folic acid and vitamin $\mathrm{B}_{12}$ through fortification may have the potential to reduce neural tube defects in this population.

The proportion of women with poor vitamin A status in the present study $(12 \%$ with serum retinol $<0.70 \mu \mathrm{mol} / \mathrm{l}$ and $63 \%$ with serum retinol $<1.05 \mu \mathrm{mol} / \mathrm{l}$ ) was lower than the prevalence of deficiency and insufficiency measured in children aged 36-59 months in Hebron and Gaza City in 2003 ( $26 \%$ and $76 \%$, respectively) using the same cut-offs without correction for inflammation ${ }^{(2)}$. Vitamin A deficiency as a public health problem is defined by the status of children according to the International Vitamin A Consultative Group and WHO criteria ${ }^{(27,28)}$. While serum retinol was not measured in children in the present study, the large proportion of women with marginal values in conjunction with the estimated prevalence of intake inadequacy in children before and after fortification justifies targeted interventions with vitamin A.

Ferritin was not analysed in samples from women; however, the higher prevalence of anaemia among women compared with children suggests their Fe status is worse. According to the simulation, Fe provided in wheat flour fortified at current levels would reduce Fe deficiency in children but would have a very modest effect on women of reproductive age. This finding is consistent with a Jordanian micronutrient survey in 2010 in which consumption of wheat flour fortified with $\mathrm{Fe}$ at a similar concentration reduced Fe deficiency and Fe-deficiency anaemia in children aged 12-59 months but not in women $^{(29)}$. Because use of higher levels of ferrous sulfate is not technically feasible, alternative Fe sources such as ferrous fumarate (up to $45 \mathrm{mg} \mathrm{Fe} / \mathrm{kg}$ ) or NaFeEDTA (up to $30 \mathrm{mg} \mathrm{Fe} / \mathrm{kg}$ ) should be considered. While either of these measures would increase $\mathrm{Fe}$ intake by approximately $30 \%$, other interventions targeted at adolescent girls and women of reproductive age might also be sought.

As one of the first surveys collecting dietary and biochemical data from the same individuals, the present study highlights discrepancies and complementarities between estimates of inadequacy based on usual intakes and biomarkers. Estimation of intake relies on accurate nutrient composition data and conversion factors for raw and cooked foods, participant recall and knowledge of nutrient bioavailability. It is possible that dietary data overestimated inadequacy prevalence of micronutrients in the present study due to: (i) outdated food composition tables with inaccurate contents of these micronutrients; (ii) under-reporting of food intakes by the interviewed population; and (iii) overcorrection for bioavailability 
factors, especially for the minerals. Given multiple potential sources of error in dietary intake data, biomarker measurement is generally considered more rigorous. However, sample handling, laboratory methodology and calibration influence results of biomarkers. Biomarker values are subject to intra-individual variability, albeit at a lower rate than nutrient intakes ${ }^{(30)}$. Finally, both dietary and biochemical data rely on the choice of cut-off points. Large discrepancies between the assessment methods may call for a re-examination of the cut-offs used.

The present study had several limitations. The dietary and biochemical survey was carried out in two of the poorest regions under the Palestinian administration and results may not be generalizable to the entire Palestinian population. In both communities, access to foods from animal sources and fresh fruits and vegetables is limited. Large and heteroscedastic intra-individual variation precluded estimation of usual intakes of vitamin $\mathrm{B}_{12}$ by women and children aged 60-83 months and calculation of the likely effect of wheat flour fortification. A single serum sample was obtained from study participants and biochemical measurements were not made for all micronutrients.

\section{Conclusion}

In conclusion, complementary dietary and biochemical data in the present study indicated a high prevalence of inadequacy of multiple micronutrients among women and children in Hebron and Gaza City. Discrepancies between the two data types, where large, signal a need to investigate why these occur and to reconsider nutrient composition and bioavailability estimates as well as cut-off points for biochemical markers. While fortification of wheat flour is predicted to reduce inadequacies of all micronutrients included in the Palestinian fortification formula, modification of fortificant concentrations of vitamin D, thiamin, vitamin $\mathrm{B}_{12}, \mathrm{Zn}$ and folic acid may be indicated. Additionally, targeted interventions for vitamin A in children and vitamin $\mathrm{D}$ and $\mathrm{Fe}$ in women of reproductive age may be needed to close intake gaps for these nutrients. A monitoring and surveillance programme of the evolution of micronutrient status of Palestinian women and children should include measurement of biomarkers for vitamin A, vitamin $\mathrm{B}_{12}, \mathrm{Fe}$ and $\mathrm{Zn}$, as well as vitamin $\mathrm{D}$, folate and thiamin in women. The feasibility of monitoring several of these vitamins in breast milk should be investigated. The results of this work are pertinent not only for planning nutritional programmes in Palestinian communities, but also as a model for designing and evaluating food fortification interventions worldwide.

\section{Acknowledgements}

Financial support: This article was made possible by the generous support of the US Agency for International
Development (USAID) under the terms of Cooperative Agreement No. GHS-A-00-05-00012-00 to FHI-360 (and before to AED). USAID had no role in the design, analysis, or writing of this article. Conflict of interest: None. Authorship: Z.A. was responsible for field work and data collection, and contributed in interpretation of results. A.'A.A. contributed in the interpretation of the results. L.H.A. advised the project, supervised biochemical analyses and assisted with data interpretation and publication. A.C. calculated estimates of usual food and nutrient intakes. O.D. acted as study coordinator. S.D. was responsible for field work and data collection. D.D. assisted with data interpretation and was responsible for manuscript preparation. R.Q. entered and cleaned data, and assisted with statistical analysis. Z.R. carried out statistical analyses. A.R. assisted with study design and liaised with the Ministry of Health of the Palestinian Authority. R.S. facilitated transfer of biological specimens and coordinated data analysis. S.S.-F. conducted biochemical analyses of the serum samples. Ethics of buman subject participation: The study was conducted according to the guidelines laid down in the Declaration of Helsinki and all procedures involving human subjects were approved by the Committee on Human Subjects Research at the Directorate of Primary Health Care and Public Health of the Ministry of Health of the Palestinian Authority, as well as the Office of Research of Al-Quds University.

\section{References}

1. Gibson R \& Ferguson E (2008) An Interactive 24-hour Recall for Assessing the Adequacy of Iron and Zinc Intakes in Developing Countries. Washington, DC: HarvestPlus, IFPRI and CIAT.

2. US Agency for International Development (2004) Prevalence of Vitamin A Deficiency among Children 12-59 Months of Age in the West Bank and Gaza Strip. West Bank and Gaza: USAID.

3. Abdeen Z \& Qasrawi R (2010) Palestinian Food: The First Palestinian National Nutrition Survey. Saarbrücken: VDM Verlag.

4. Jones KM, Ramirez-Zea M, Zuleta C et al. (2007) Prevalent vitamin B-12 deficiency in twelve-month-old Guatemalan infants is predicted by maternal B-12 deficiency and infant diet. J Nutr 137, 1307-1313.

5. Institute of Medicine (2001) Dietary Reference Intakes for Vitamin A, Vitamin K, Arsenic, Boron, Chromium, Copper, Iodine, Iron, Manganese, Molybdenum, Nickel, Silicon, Vanadium, and Zinc. Washington, DC: National Academies Press.

6. Nusser SM, Carriquiry AL, Dodd KW et al. (1996) A semiparametric approach to estimating usual nutrient intake distributions. J Am Stat Assoc 91, 1440-1449.

7. Centers for Disease Control and Prevention (2004) National Health and Nutrition Examination Survey 2003-2004. Hyattsville, MD: CDC.

8. Abdeen Z, Allen L, Carriquiry A et al. (2010) Determining the Dietary Pattern and Biochemical Markers among Women and Children in Hebron and Gaza City. Washington, DC: A2Z.

9. Carriquiry AL (2003) Estimation of usual intake distributions of nutrients and foods. J Nutr 133, issue 2, 601S-608S. 
10. Foote JA, Murphy SP, Wilkens LR et al. (2004) Dietary variety increases the probability of nutrient adequacy among adults. J Nutr 134, 1779-1785.

11. Institute of Medicine (2010) Dietary Reference Intakes for Calcium and Vitamin D [AC Ross, CL Taylor, AL Yaktine et al., editors]. Washington, DC: National Academies Press.

12. Institute of Medicine (2000) Dietary Reference Intakes: Applications in Dietary Assessment. Washington, DC: National Academies Press.

13. Keagy PM, Stokstad EIR \& Feller DA (1975) Folacin stability during bread processing and family flour storage. Cereal Chem 52, 348-356.

14. Maleki M \& Daghir S (1967) Effect of baking on retention of thiamine, riboflavin, and niacin in Arabic bread. Cereal Chem 44, 483-487.

15. Parrish DB, Eustace WD, Ponte JG et al. (1980) Distribution of vitamin $\mathrm{A}$ in fortified flours and effect of processing, simulated shipping, and storage. Cereal Chem 57, 284-287.

16. Parrish DB, Herod L, Ponte JG et al. (1980) Recovery of vitamin A in processed foods made from fortified flours. J Food Sci 45, 1438-1439.

17. Ranhotra GS \& Gelroth JA (1986) Stability of enrichment vitamins in bread and cookies. Cereal Chem 63, 401-403.

18. Tabekhia MM \& D'Appolonia BL (1979) Effects of processing steps and baking on thiamine, riboflavin, and niacin levels in conventional and continuous produced bread. Cereal Chem 56, 79-81.

19. Ottaway PB (2002) The stability of vitamins during food processing. In The Nutrition Handbook for Food Processors pp. 247-264 [CJK Henry and C Chapman, editors]. Abington: Woodhead Publishing.
20. Fleiss L, Levin B \& Paik M (2003) Statistical Methods for Rates and Proportions, 3rd ed. Indianapolis, IN: Wiley.

21. Gannage-Yared MH, Chemali R, Yaacoub N et al. (2000) Hypovitaminosis D in a sunny country: relation to lifestyle and bone markers. J Bone Miner Res 15, 1856-1862.

22. Gharaibeh MA \& Stoecker BJ (2009) Assessment of serum $25(\mathrm{OH}) \mathrm{D}$ concentration in women of childbearing age and their preschool children in Northern Jordan during summer. Eur J Clin Nutr 63, 1320-1326.

23. Hekimsoy Z, Dinc G, Kafesciler S et al. (2010) Vitamin D status among adults in the Aegean region of Turkey. BMC Public Health 10, 782.

24. Hovsepian S, Amini M, Aminorroaya A et al. (2011) Prevalence of vitamin $\mathrm{D}$ deficiency among adult population of Isfahan City, Iran. J Health Popul Nutr 29, 149-155.

25. Dary O (2009) Nutritional interpretation of folic acid interventions. Nutr Rev 67, 235-244.

26. Ray JG, Wyatt PR, Thompson MD et al. (2007) Vitamin $B_{12}$ and the risk of neural tube defects in a folic-acid-fortified population. Epidemiology 18, 362-366.

27. de Pee S \& Dary O (2002) Biochemical indicators of vitamin A deficiency: serum retinol and serum retinol binding protein. J Nutr 132, 9 Suppl., 2895S-2901S.

28. World Health Organization (2011) Vitamin A Supplementation in Infants and Children 6-59 Months of Age. Geneva: WHO

29. Jordan Ministry of Health (2011) National Micronutrient Survey Jordan 2010. Amman: JMH.

30. Taylor CL, Carriquiry AL, Bailey RL et al. (2013) Appropriateness of the probability approach with a nutrient status biomarker to assess population inadequacy: a study using vitamin D. Am J Clin Nutr 97, 72-78. 